\title{
WATER BEETLES (INSECTA: COLEOPTERA) OF SOME PEATLANDS IN THE NORTH CAUCASUS
}

\author{
Alexander A. Prokin ${ }^{1,2, *}$, Alexey S. Sazhnev ${ }^{1}$, Dmitriy A. Philippov ${ }^{1}$ \\ ${ }^{1}$ Papanin Institute for Biology of Inland Waters RAS, Russia \\ *e-mail:prokina@mail.ru \\ ${ }^{2}$ Cherepovets State University, Russia
}

Received: 23.12.2018. Revised: 02.03.2019. Accepted: 05.03.2019.

\begin{abstract}
Montane peatlands occupy only $0.1 \%$ of the Caucasus territory and are present at altitudes of 600-3400 m a.s.l. Unlike vegetation and stratigraphy, insects of the peatlands have been studied poorly. The aim of our study is to describe for the first time the fauna of water beetles of Sphagnum and Carex-Sphagnum peatlands in the North Caucasus, its zoogeographical and regional specifics, and factors determining species richness and species composition of water beetles in several peatlands. The fieldwork was performed in May, June, and September, 2018, in eight peatlands in North Ossetia (Tarskoe, Chifandzar, and two peatlands on the Kubus Mount and Kabardino-Balkaria (three small peatlands near Verkhnyaya Balkaria village and the «narzan» (with emissions of mineral groundwater) Ushtulu peatland). The material was collected in the in-mire water bodies and watercourses by sweeping with a Balfour-Brown aquatic net, collecting individuals with aquarium nets in shallow water bodies, and trampling of Sphagnum. We recorded 25 species of water beetles of six families: Gyrinidae (1), Haliplidae (1), Dytiscidae (13), Helophoridae (2), Hydrophilidae (7), and Hydraenidae (1). Among them, there are endemics, and subendemics of the Caucasus boreal montane species which are glacial relicts of the region. Development of the local fauna of water beetles in the North Caucasus peatlands has regional specifics and depends on altitudes, typological diversity of the peatland water bodies, and physical and chemical properties of water. We recommend establishing new Protected Areas in Russia: Sphagnum peatlands in Kabardino-Balkaria near the village Verkhnyaya Balkaria. For protection of montane Sphagnum peatlands as unique habitats, we recommend to include the boreal-montane species Hydroporus incognitus and Hydroporus nigellus in the Red Data Book of Kabardino-Balkaria and Hydroporus nigellus in the Red Data Book of North Ossetia.
\end{abstract}

Key words: Carex-Sphagnum peatlands, conservation, fauna, Kabardino-Balkaria, North Ossetia, regional specifics, species richness, Sphagnum peatlands, zoogeography

\section{Introduction}

Montane mires of the Caucasus are unique formations of nature at altitudes of $600-3400 \mathrm{~m}$ a.s.l. that occupy $0.1 \%$ of the area in this region (Botch \& Mazing, 1979). Most common ones are mires associated with lakes, mires formed as a result of an overflowing montane stream, and slope mires (Katz, 1971). They started to develop 4900-2500 years ago (Knyasev et al., 1992). Their development was accompanied by changes in vegetation as a result of rapid climate changes and the Holocene humidity (Tumadzanov, 1955; Neustadt, 1957), and catastrophic events (mudflows, landslides, and earthquakes) (Barsegyan, 1978). Nowadays, mires of this territory can be divided into Carex, Carex-Sphagnum, Sphagnum, and Carex-Hypnales types (Katz, 1971). Montane mires in the Caucasus were mainly studied from geobotanical and stratigraphic perspectives (Busch \& Busch, 1926; Busch, 1932; Dokturowsky, 1936; Panjutin, 1942; Akatov, 1986), with emphasis on Sphagnum mosses (Dokturowsky, 1927; Zedelmeyer, 1927; Zerov,
1935; Dylevskaya, 1976; Akatova, 2002; Doroshina \& Nikolajev, 2017, 2018). Studies on the structure of other groups are scarce (Voronikhin, 1934; Tarnogradsky, 1947, 1957, 1959; Prokina \& Philippov, 2017).

The order Coleoptera is one of the most diverse, not only in the world, but also in recent continental water bodies. About 12600 species of the world fauna $(3 \%$ of the total number of beetle species) are associated with an aquatic environment. Together with all undescribed species, their number is estimated at about 8000 (Jäch \& Balke, 2008). If we accept the estimation of the total number of animal species living in continental water bodies as 125530 (Balian et al., 2008), the proportion of aquatic beetles, including undescribed species, should be over $14 \%$ of this fauna (Ponomarenko \& Prokin, 2015). To date, there are no publications devoted to studies of such an important and diverse group of the Sphagnum peatlands in the Caucasus. Thus, our study is the first dedicated to this topic. At the same time, there are a lot of publications about 
fauna and ecology of water beetles in peatlands of other regions (Cuppen, 1986; Eyre et al., 1986; Juliano, 1991).

Studies of Quaternary deposits of Europe have shown considerable changes in ranges of water beetles during glaciation and extinction of many populations (Abellán et al., 2011). The special importance of the study of water beetles in the Sphagnum peatlands in the Caucasus is connected with the glacial age of these ecosystems in the region, as very important for the creation of a complete picture of their fauna as a whole, the history of formation and peculiarities of this process.

The level of species diversity of water beetles positively correlates with that of other groups of water macroinvertebrates (Plecoptera, Trichoptera, Mollusca, Heteroptera, Ephemeroptera). It may constitute a large part of the total community diversity of a particular biotope and can be used in bioindication (Sánchez-Fernández et al., 2006). In addition, for bioindication of the state of water bodies, it is proposed to estimate the proportion of species of certain functional groups that have been selected taking into account the life strategy, methods of breathing and feeding (Usseglio-Polatera et al., 2001). Thus, the study of the fauna and ecology of water beetles of the Caucasus will allow us in the future to solve the problems of bioindication and monitoring of aquatic ecosystems of the region.

The aim of our study is to describe the fauna of the water beetles in the Sphagnum and CarexSphagnum peatlands in the North Caucasus and describe its zoogeographical and regional specifics and factors determining species richness and species composition of the water beetles in several peatlands.

\section{Material and Methods}

Fieldwork was performed in May - June, and September, 2018 in North Ossetia and Kabardino-Balkaria. We studied a total of eight peatlands (Table 1).

The Tarskoe peatland was studied in the Prigorodny District of North Ossetia (Fig. 1A). It is one of the most famous peatlands in the North Caucasus (Tarnogradsky, 1947; Tumadzanov, 1955; Neustadt, 1957; Botch \& Mazing, 1979; Doroshina \& Nikolajev, 2017; Prokina \& Philippov, 2017). Among all peatlands of the North Caucasus situated below $1000 \mathrm{~m}$ a.s.l., it is the only one, where Sphagnum mosses are present (Zerov, 1935). This peatland harbours seven Sphagnum species (Doroshina \& Nikolajev, 2017; authors' unpublished data). The Tarskoe peatland was formed in the mid-Holocene (Tumadzanov, 1955). In the first third of the $20^{\text {th }}$ century, it was a tussocky Sphagnum-dominated meso-oligotrophic peatland with pools (Tarnogradsky, 1947). The drainage and peat extraction of the peatland started in 1939. Canals and ditches for the land development were constructed. Nowadays, the peatland is at the stage of recovery. Grass mesophilic communities are dominating, including Sphagnum associated only with ditches. The peatland is preserved as a natural monument of the region. Three peatlands (Chifandzar, and upper and lower peatlands of the Kubus mountain) were studied within the National Park «Alania», the Irafsky District.

Table 1. Characteristics of peatlands and several water bodies of peatlands

\begin{tabular}{|c|c|c|c|c|c|c|c|}
\hline $\begin{array}{c}\text { Name } \\
\text { (abbreviation) }\end{array}$ & Co-ordinates & $\begin{array}{c}\text { Altitude, } \\
\text { m a.s.l. }\end{array}$ & Peatland area, $\mathrm{km}^{2}$ & water bodies, month & $\mathrm{pH}$ & Water $\mathrm{t},{ }^{\circ} \mathrm{C}$ & $\begin{array}{c}\text { Total dissolved } \\
\text { solids (TDS), ppm }\end{array}$ \\
\hline Tarskoe $(\mathrm{T})$ & \begin{tabular}{|l}
$42.963056 \mathrm{~N}$, \\
$44.726111 \mathrm{E}$ \\
\end{tabular} & 800 & 0.0534 & drainage ditch, VI (IX) & $6.1-6.2(4.9)$ & $16.3(16.5)$ & 37 \\
\hline \multirow{2}{*}{ Chifandzar (Ch) } & \multirow{2}{*}{$\begin{array}{l}42.918889 \mathrm{~N} \\
43.513889 \mathrm{E}\end{array}$} & \multirow{2}{*}{2289} & \multirow{2}{*}{0.5560} & brook, VI & 6.8 & $11.2-12.2$ & 16 \\
\hline & & & & hollow-pool, IX & $4.6-5.5$ & $11-15$ & $10-20$ \\
\hline Kubus low (Kl) & $\begin{array}{l}42.892500 \mathrm{~N}, \\
43.576389 \mathrm{E}\end{array}$ & 2077 & 0.0049 & hollow-pool, VI & 7.0 & 10.5 & 7 \\
\hline Kubus top (Kt) & $\begin{array}{l}42.893333 \mathrm{~N}, \\
43.577222 \mathrm{E}\end{array}$ & 2080 & 0.0020 & hollow-pool, VI(IX) & $5.9(7.1)$ & $10.5(17.5)$ & $7(7)$ \\
\hline \multirow[b]{2}{*}{ Konskoe (K) } & \multirow[b]{2}{*}{$\begin{array}{l}43.100833 \mathrm{~N} \\
43.490000 \mathrm{E}\end{array}$} & \multirow[b]{2}{*}{1776} & \multirow[b]{2}{*}{0.0002} & in-mire lake, VI(IX) & $6.7(5.3-5.5)$ & $23.8(16-19)$ & $42(40)$ \\
\hline & & & & $\begin{array}{l}\text { temporary pool in the } \\
\text { depression after peat } \\
\text { excavation, VI }\end{array}$ & 6.8 & 20.9 & 21 \\
\hline Zayachye (Z) & $\begin{array}{l}43.097778 \mathrm{~N}, \\
43.478056 \mathrm{E}\end{array}$ & 1810 & 0.0001 & in-mire lake, VI(IX) & $4.3(3.7-4.9)$ & $\begin{array}{l}12.4-15 \\
(13-16)\end{array}$ & $32(40)$ \\
\hline Vysokoe (V) & $\begin{array}{l}43.096944 \mathrm{~N}, \\
43.478889 \mathrm{E}\end{array}$ & 1836 & 0.0015 & in-mire lake, VI(IX) & $4.9-5.1(3.3)$ & $\begin{array}{c}14-14.4 \\
(11.5)\end{array}$ & $20(30)$ \\
\hline Ushtulu (U) & $\begin{array}{l}42.974722 \mathrm{~N} \\
43.334722 \mathrm{E}\end{array}$ & 1995 & 0.1730 & pools, VI(IX) & $5.4(5.8)$ & $\begin{array}{c}17.4-19.1 \\
(16.5)\end{array}$ & $54-100(60)$ \\
\hline
\end{tabular}




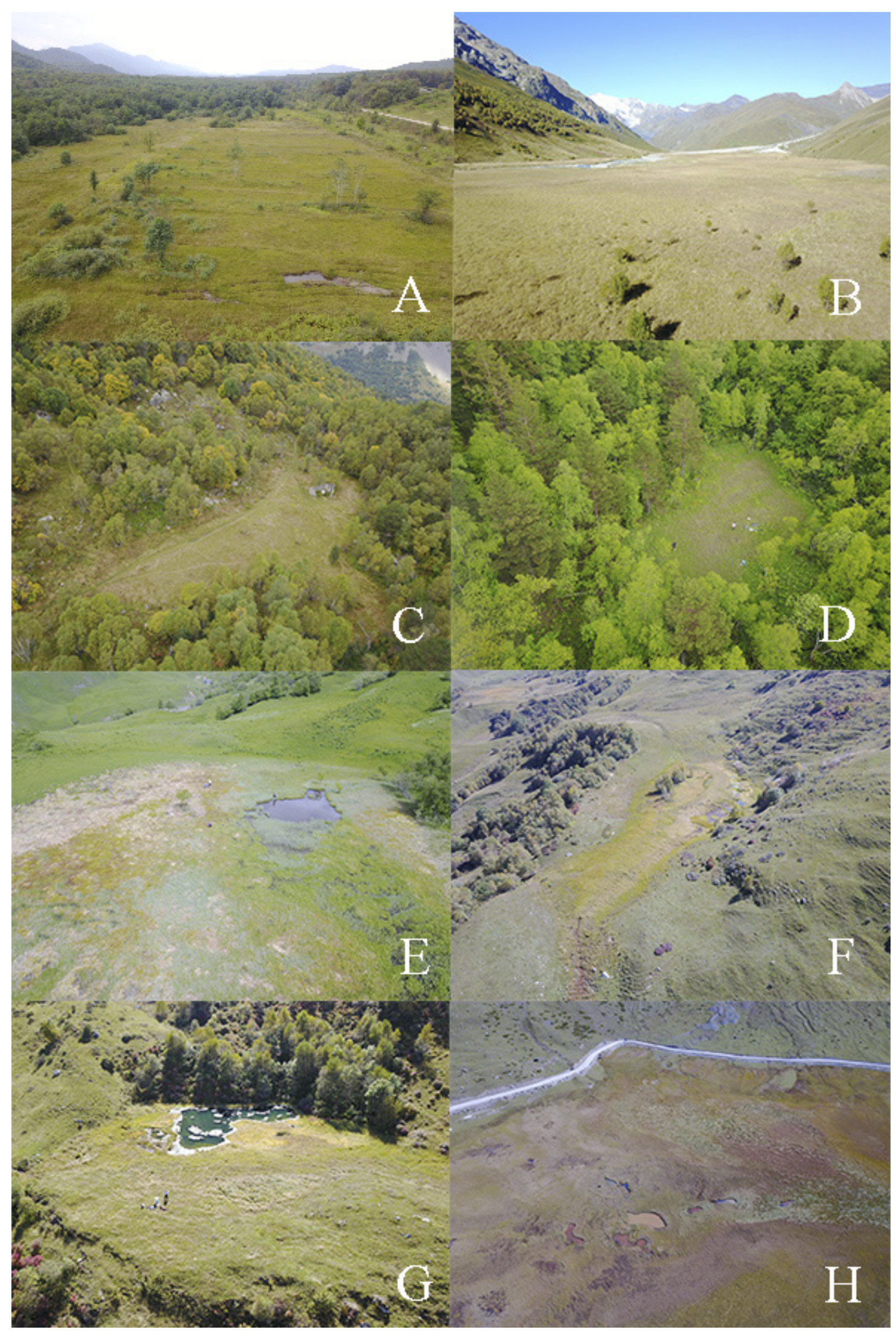

Fig. 1. Studied peatlands: A - Tarskoe, B - Chifandzar, C - lower Kubus, D - upper Kubus, E - Konskoe, F - Zayachye, G - Vysokoe, H - Ushtulu. 
Chifandzar (Fig. 1B) is one of the biggest mires of North Ossetia. The peatland has been formed around 5000 years ago (Knyasev et al., 1992) in the upper reaches of the River Haresidon. The Chifandzar peatland is an even area on the fluvial terrace above the floodplain of the left bank of the river. Its microrelief is tussocky. The vegetation is dominated by Carex spp., while Sphagnum is scarce (Doroshina \& Nikolajev, 2018; authors' unpublished data). Chifandzar can be described as a Carex and Carex-Sphagnum eutrophic peatland. There are small Sphagnum pools, laggs flowing into brooks, hollows between hummocks, and brooks in some places disappearing inside peat deposits. Nowadays, grazing takes place at the peatland itself and the adjacent slopes.

The upper and lower peatlands of the Kubus Mountain (Fig. 1C, 1D) are small oligotrophic Sphagnum peatlands with an even or slightly hummocky terrain with hollows. The vegetation is dominated by Sphagnum and Carex-Sphagnum communities. The Kubus upper peatland includes a very small (area is about $2 \mathrm{~m}^{2}$ ) secondary pool and several smaller Carex-Sphagnum hollowpools. The Kubus lower peatland is less waterlogged; water bodies are present in places with rocks near the peatland.

Four mires were studied in the Cherekskiy District of Kabardino-Balkaria. Three of them are near the village Verkhnyaya Balkaria. Their names (Konskoe (Fig. 1E), Zayachye (Fig. 1F), and Vysokoe (Fig. 1G)) are not official, because the areas of the peatlands are not bigger than $0.01 \mathrm{~km}^{2}$, and local people call them «lakes» or «mires». All three peatlands have a limnogeneous origin (Busch, 1932). In the middle of each of them, there is a residual drainage lake surrounded by Carex, Carex-Sphagnum, and Sphagnum communities. These peatlands can be described as oligotrophic, partially meso-oligotrophic. It is interesting that Sphagnum fuscum (Schimp.) H. Klinggr. covers a considerable area of all three peatlands, forming dense communities on tussocks and in even areas. Konskoe and Zayachye peatlands have traces of burning of plants indicated by Molinia coerulea (L.) Moench. The peatlands near the village Verkhnyaya Balkaria are not under protection.

The Ushtulu peatland (Fig. 1H) is an eutrophic Carex and partially Carex-Sphagnum slope peatland with emissions of mineral («narzan») groundwater. The vegetation is dominated mostly by Carex rostrata Stokes. The peatland includes grass, grass-Hypnales, grass-Sphagnum water bod- ies, and several secondary small lakes $(0.5-2.0 \mathrm{~m}$ in depth and 10-100 $\mathrm{m}^{2}$ in area). This assemblage is included in the Kabardino-Balkaria State HighMountain Reserve.

Physical and chemical characteristics of water were measured in all studied peatland water bodies with portable HI 98201 and Combo HI 98129 devices (Hanna Instruments). The third author performed an aerial survey (aerial photography and video recording) with a DJI Mavic Pro multirotor. The eTrex Vista H (Garmin) device was used as a GPS-receiver and altimeter. The mire's typology is used according to Rydin \& Jeglum (2013) and Joosten et al. (2017).

Material was collected following the published recommendations for hydrobiological studies of mires (Philippov et al., 2017) by sweeping with a Balfour-Brown aquatic net, collecting of individuals with aquarium nets in shallow basins, and trampling of Sphagnum. The material was fixed in $96 \%$ ethanol.

Identification of beetles was performed in the laboratory using special literature (Zaitzev, 1927, 1953; Hansen, 1987; Jäch, 1987; Angus, 1992; Nilsson \& Holmen, 1995; Tsalolikhin, 2001; Fery \& Petrov, 2005; van Vondel et al., 2006; Fery, 2009) and by using a Micromed MC-2 ZOOM stereo microscope. Dissection of the genitalia and mounting of the specimens were performed using the standard technique according to Golub et al. (2012).

The majority of the collected material is deposited in the Papanin Institute for Biology of Inland Waters RAS (IBIW RAS), Borok. Some of the material is deposited in the Zoological Institute RAS (ZISP), Saint Petersburg, and the Entomology Department, Lomonosov Moscow State University (DEUM), Moscow.

Information on the species range was taken from these published catalogues: Haliplidae (Van Vondel, 2017), Dytiscidae (Hájek, 2017), Hydraenidae (Jäch, 2015), Helophoridae (Fikáček et al., 2015a), and Hydrophilidae (Fikáček et al., 2015b).

The species range was classified according to Yemel'yanov (1974). According to this source, the species range that has its eastern borders inside the western sharply continental subsector of the western Palearctic belongs to the super-Atlantic range. And the ranged limited in the west by the western subcontinental sector of the Palearctic in the zone of the Atlantic Ocean influence belongs to the Panatlantic range.

The dendrogram of the faunistic similarity of the peatlands was made by a method based on the Sørensen - Dice coefficient using the PAST 3.0 
software. We determined the dependence of the species richness on the altitude and area of lakes using permutational regression analysis with the complete number of permutations (40320).

\section{Results}

A total of 25 species of six families of water beetles were found in the studied peatlands: Gyrinidae (1 species), Haliplidae (1), Dytiscidae (13), Helophoridae (2), Hydrophilidae (7), and Hydraenidae (1). The genera of Dytiscidae represented by more than one species were Hydroporus ( 7 species) and Agabus (3). In the Hydrophilidae family, two species represented the genus Enochrus (Table 2).

Two species of the studied fauna have been recorded for the first time in Russia: Hydraena pontica Janssens, 1963 and Helophorus hilaris Sharp, 1916 (Prokin \& Sazhnev, 2019). Two species have been recorded for the first time in the North Caucasus: Haliplus sibiricus Motschulsky, 1860, Hydroporus nigellus Mannerheim, 1853 (Prokin \& Sazhnev, 2019). And two species have been recorded for the first time in the North Caucasus and Kabardino-Balkaria: Helophorus discrepans Rey, 1885, and Chaetarthria seminulum (Herbst, 1797) (Prokin \& Sazhnev, 2019). Prokin \& Sazhnev (2019) also recorded Enochrus affinis (Thunberg, 1794) for the first time in the North Caucasus, and Agabus congener (Thunberg, 1794), Hydroporus incognitus Sharp, 1869, and Anacaena lutescens (Stephens, 1829) in Kabardino-Balkaria.

We determined 14 types of species range, including longitudinal, latitudinal and altitudinal characteristics, or the ones limited by the provinces of the Caucasus (Table 2). Six species are of the temperate super-Atlantic range type.

Table 2. Taxonomic composition and types of species range of water beetles of studied peatlands

\begin{tabular}{|c|c|c|c|c|c|c|c|c|c|}
\hline \multirow{2}{*}{ Taxa } & \multirow{2}{*}{ Range type } & \multicolumn{4}{|c|}{ North Ossetia } & \multicolumn{4}{|c|}{ Kabardino-Balkaria } \\
\hline & & $\mathrm{T}$ & $\mathrm{Ch}$ & $\mathrm{Kl}$ & $\mathrm{Kt}$ & $\mathrm{K}$ & Z & $\mathrm{V}$ & $\mathrm{U}$ \\
\hline \multicolumn{10}{|c|}{ Family Gyrinidae Latreille, 1802} \\
\hline Gyrinus substriatus Stephens, 1828 & sA, b-s & + & - & - & - & - & - & - & - \\
\hline \multicolumn{10}{|c|}{ Family Haliplidae Aubé, 1836} \\
\hline Haliplus sibiricus Motschulsky, 1860 & $\mathrm{P}, \mathrm{a}-\mathrm{sb}$ & - & - & - & - & - & - & + & - \\
\hline \multicolumn{10}{|c|}{ Family Dytiscidae Leach, 1815} \\
\hline Acilius sulcatus (Linnaeus, 1758) & $\mathrm{P}, \mathrm{b}-\mathrm{s}$ & - & - & - & - & + & - & - & - \\
\hline Agabus bipustulatus (Linnaeus, 1767) & sA, a-tr* & + & + & + & + & - & - & - & - \\
\hline A. congener (Thunberg, 1794) & $\mathrm{P}, \mathrm{a}-\mathrm{sb}$ & + & + & + & + & + & + & + & + \\
\hline A. conspersus (Marsham, 1802) & $\mathrm{sA}, \mathrm{sb}$ & + & - & - & - & - & - & - & - \\
\hline Dytiscus m. marginalis Linnaeus, 1758 & $\mathrm{sA}, \mathrm{t}$ & - & - & - & - & + & - & - & - \\
\hline Hydroporus incognitus Sharp, 1869 & $\mathrm{sA}, \mathrm{b}-\mathrm{m}$ & - & - & - & - & + & + & + & - \\
\hline H. jacobsoni Zaitzev, 1927 & $\mathrm{C}$ & - & - & + & - & - & - & - & - \\
\hline H. marginatus (Duftschmid, 1805) & $\mathrm{sA}, \mathrm{sb}$ & + & + & + & + & - & - & - & - \\
\hline H. palustris (Linnaeus, 1761) & sA, b-s & + & - & - & - & - & - & - & - \\
\hline H. planus (Fabricius, 1781) & $\mathrm{sA}, \mathrm{t}$ & + & - & - & - & - & - & - & - \\
\hline H. tessellatus (Drapiez, 1819) & $\mathrm{pA}, \mathrm{sb}$ & + & - & - & - & + & - & - & - \\
\hline H. nigellus Mannerheim, 1853 & $\mathrm{H}, \mathrm{a}-\mathrm{b}-\mathrm{m}$ & - & + & - & - & - & - & + & - \\
\hline Ilybius fuliginosus (Fabricius, 1792) & $\mathrm{sA}, \mathrm{t}$ & - & - & - & - & - & - & + & - \\
\hline \multicolumn{10}{|c|}{ Family Helophoridae Leach, 1815} \\
\hline Helophorus discrepans Rey, 1885 & $\mathrm{pA}, \mathrm{t}$ & - & + & - & - & + & - & - & - \\
\hline H. hilaris Sharp, 1916 & $\mathrm{C}$ & - & - & - & - & + & + & - & - \\
\hline \multicolumn{10}{|c|}{ Family Hydrophilidae Latreille, 1802} \\
\hline Anacaena lutescens (Stephens, 1829) & $\mathrm{H}, \mathrm{t}$ & + & + & + & + & + & + & + & - \\
\hline Chaetarthria seminulum (Herbst, 1797) & $\mathrm{sA}, \mathrm{t}$ & + & - & - & - & + & - & + & - \\
\hline Coelostoma orbiculare (Fabricius, 1775) & $\mathrm{P}, \mathrm{t}$ & + & - & - & - & + & + & - & + \\
\hline Enochrus affinis (Thunberg, 1794) & $\mathrm{P}, \mathrm{t}$ & + & - & - & - & - & - & - & - \\
\hline E. fuscipennis (Thomson, 1884) & $\mathrm{sA}, \mathrm{t}$ & + & - & - & - & - & - & - & + \\
\hline Helochares obscurus (Müller, 1776) & $\mathrm{sA}, \mathrm{t}$ & + & - & - & - & + & + & + & - \\
\hline Hydrobius fuscipes (Linnaeus, 1758) (s. 1.) & $\mathrm{H}, \mathrm{b}-\mathrm{s}$ & + & - & - & - & + & + & + & - \\
\hline \multicolumn{10}{|c|}{ Family Hydraenidae Mulsant, 1844} \\
\hline Hydraena pontica Janssens, 1963 & $\mathrm{C}$ & - & - & - & - & + & - & - & - \\
\hline Total: & & 15 & 6 & 5 & 4 & 13 & 7 & 9 & 3 \\
\hline
\end{tabular}

Note: Names of the peatlands: T - Tarskoe, $\mathrm{Ch}$ - Chifandzar, Kl - Kubus low, Kt - Kubus top, K - Konskoe, Z - Zayachye, V - Vysokoe, U - Ushtulu. Types of species range, longitudinal groups: H - Holarctic, P - trans-Palearctic, sA - super-Atlantic, pA - pan-Atlantic. Types of species range, latitudinal groups: a-b-m - Arctic-euboreal mountain, a-sb - Arctic-subboreal, a-tr - Arctic-tropical, b-m - euboreal-mountain, $\mathrm{t}$ - temperate (euboreal-subboreal), b-s - euboreal-subtropical, sb - subboreal; $\mathrm{C}$ - Caucasian, * - extending in the Afrotropics. 
Most of the longitudinal range types belong to the super-Atlantic type (10). We also found many transitional Palearctic species (5), fewer Holarctic (3) species, and only two pan-Atlantic species.

Most of the latitudinal range types belong to the temperate type (10), fewer to the EuborealSubtropic (4) and Subboreal (3) types. The rest of the latitudinal range types are represented by one or two species (Table 2).

We recorded three endemic and subendemic species for the Caucasus (12\%). Two species have boreal-mountain types of range: euboreal-mountain Hydroporus incognitus and Arcto-euboreal mountain Hydroporus nigellus (Dytiscidae), which has isolated populations in the Pyrenees, Alps, Caucasus, and Altai (Nilsson \& Holmen, 1995). According to Angus (1992), Helophorus discrepans has isolated populations in the Pyrenees, Alps, Carpathian, Turkey, Iran, and Atlas mountains. But this species does not have a latitudinal disjunction of the range in Europe. Despite the fact that its distribution should formally belong to the temperate type, it is similar to the boreal-mountain in origin, and the current distribution of the species on the plains of the sub-boreal range can be explained by the secondary recovery of species range.

The highest species richness of water beetles has been recorded in the Tarskoe (15 species) and Konskoe (13) peatlands. The lowest species richness has been recorded in the extremely mineralised «narzan» Ushtulu peatland (3) and in the upper Kubus peatland (4), where the microrelief is not developed. And the only water body of the peatland is a secondary small acidic lake in the middle of the peatland (Table 1). We recorded five to nine species in the other peatlands (Table 2).

The highest occurrence frequency of species has been recorded for Agabus congener (100.0\%), and Anacaena lutescens (87.5\%), which was only absent in the «narzan» Ushtulu peatland (Table 2). Agabus congener and Anacaena lutescens occur in peatland pools, hollows, original lakes, and brooks. In addition, Anacaena lutescens also occurs in water bodies between tussocks and in Sphagnum.

Agabus bipustulatus and Hydroporus marginatus are recorded in all peatlands of North Ossetia, but are absent in all peatlands of Kabardino-Balkaria. On the other hand, the euboreal-mountain Hydroporus incognitus is recorded in the Konskoe, Zayachye, and Vysokoe peatlands, but is absent in North Ossetia.

Ten species were found only in one of the studied peatlands, in the Tarskoe (4 species), lower Kubus (1), Konskoe (3), and Vysokoe (2) peatlands (Table 2).

All unique species of the Tarskoe peatland are indicative of plains and low mountains, and they are not found in the middle or high mountains: $G y$ rinus substriatus, Agabus conspersus, Hydroporus palustris, H. planus, and Enochrus affinis. These species have trans-Palearctic or super-Atlantic types of the species range, not extending in the north farther than the taiga, or are even limited to the sub-boreal zone (A. conspersus).

The Caucasian endemic Hydroporus jacobsoni is recorded only in an area where a slope bog enters the lower Kubus peatland. This bog connects the lower Kubus peatland with the upper Kubus peatland located on the slope above.

Helophorus hilaris and Hydraena pontica, mainly distributed in the Transcaucasia, are recorded in a zone of removed peat used as a watering place for horses in the Konskoe peatland, covered with a eutrophic herbaceous vegetation at the border of the burned area. At the beginning of June, this watering place is a temporary water body with $\mathrm{pH}$ close to neutral (Table 1) and high temperatures (up to $21^{\circ} \mathrm{C}$ ). Helophorus hilaris has also been recorded from the edge of the in-mire lake in the Zayachye peatland.

Haliplus sibiricus and Ilybius fuliginosus have been recorded from the original lake of the Vysokoe peatland. Both species are indicative of permanent water bodies (streams and lakes). Two large species of water beetles, Acilius sulcatus and Dytiscus marginalis, belong to this ecological group, too. They are recorded in the original lake of the Konskoe peatland. It is noteworthy that these species are absent in the Zayachye peatland, which has the lowest $\mathrm{pH}$ (up to 3.7) (Table 1).

The species richness is in inverse proportion to the $\mathrm{m}$ a.s.l. of the lake (the regression coefficient is $-0.008, p=0.007)$ and it does not depend on the area of the lake $(p=0.595)$.

Analysis of the faunistic similarities between peatlands shows the presence of two geographical groups in which the similarity is $>50 \%$ (Fig. 2). These are the group of the North-Ossetia peatlands (upper and lower Kubus) and the Chifandzar peatland and the group of Kabardino-Balkaria peatlands (Konskoe, Zayachye and Vysokoe). The Tarskoe peatland is formally close to the Kabardino-Balkaria peatlands with a high species richness, but the similarity between them is $<50 \%$. The Ushtulu peatland, with the lowest species richness of water beetles, is joined with other peatlands at a level of $40 \%$ similarity. 


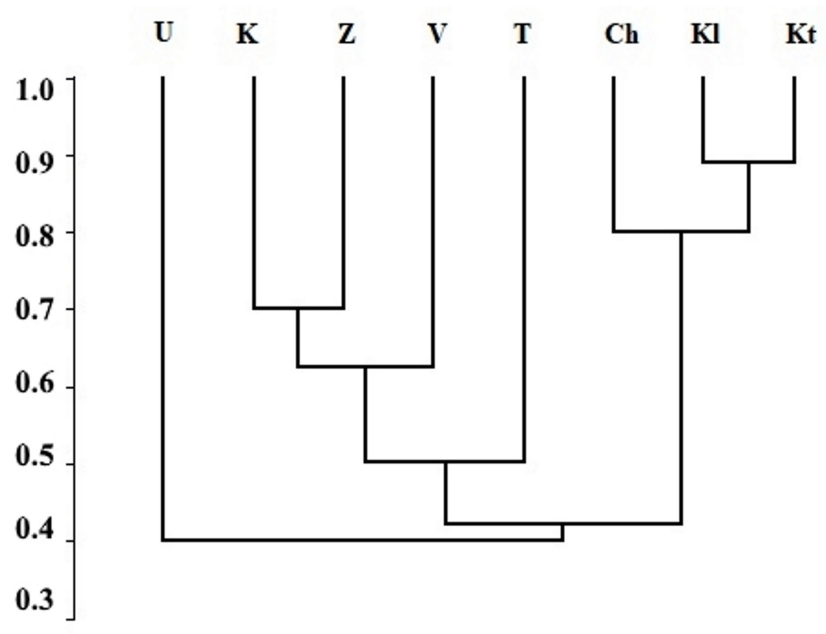

Fig. 2. Dendrogram of faunistic similarity between peatlands. Names of the peatlands: $\mathrm{T}-$ Tarskoe, $\mathrm{Ch}-$ Chifandzar, $\mathrm{Kl}-$ Kubus low, Kt - Kubus top, $\mathrm{K}$ - Konskoe, Z - Zayachye, V - Vysokoe, U - Ushtulu.

\section{Discussion}

The development of the local fauna of water beetles of the North Caucasus peatlands has regional specifics, which is demonstrated by the analysis of the faunistic similarities and presence of peculiar species for North Ossetia (Agabus bipustulatus and Hydroporus marginatus) and KabardinoBalkaria (Hydroporus incognitus).

Post-glacial colonisation is probably the most likely way of spreading for species with boreal-mountain type of the species range in the region, associated with montane Sphagnum peatlands in the Caucasus. The velvet water bug Hebrus ruficeps Thomson, 1871 (Heteroptera: Hebridae) recorded in the Zayachye peatland of Kabardino-Balkaria (Prokin, 2018) belongs to this group. New glacial relicts in the sense of Mani (1968) will probably be found among other groups of insects in the Sphagnum peatlands of the region.

The high diversity of the species range of the studied fauna shows a complicated history of its origin, because it includes old Holarctic zoogeographic elements: boreal-mountain elements formed during the post-glacial period, and autochthonous endemics of the Caucasus.

The altitude plays an important role in colonisation of the peatlands. The species richness is in inverse proportion to the altitude of the peatland. Several species (Gyrinus substriatus, Agabus conspersus, Hydroporus palustris, H. planus and Enochrus affinis), limited by foothills, have been recorded only in the Tarskoe peatland, situated at the lowest altitude among the studied ones (800 $\mathrm{m}$ a.s.1.).
Another factor of the development of the specific fauna of individual peatlands is the typological diversity of peatland water bodies. Haliplus sibiricus, Ilybius fuliginosus, Acilius sulcatus, and Dytiscus marginalis are indicative of original peatland water bodies and prefer permanent water bodies (Nilsson \& Holmen, 1995; Boukal et al., 2007). Some species with mostly Transcaucasian distributional range are associated with warm temporary water bodies on the border of the peatlands (Helophorus hilaris, Hydraena pontica). The Caucasus endemic species Hydroporus jacobsoni is recorded only near the slope peatland.

\section{Conclusions}

The identified factors of the development of the fauna of water beetles of the peatlands in the North Caucasus explain the necessity to contribute to the typological diversity of the peatland water bodies as habitats of Caucasian endemics and boreal-mountain relicts. It is advisable to establish new Protected Areas in Russia: the Konskoe, Zayachye, and Vysokoe peatlands in Kabardino-Balkaria. It is necessary to strengthen the protection of the current Protected Areas of Russia and to prohibit any grazing, burning of plants, peat extraction, or hay production in the watershed of the peatlands.

To protect the montane Sphagnum peatlands as unique species habitats, we recommend including the boreal-mountain species Hydroporus incognitus and Hydroporus nigellus in the Red Data Book of the Kabardino-Balkaria and Hydroporus nigellus in the Red Data Book of North Ossetia, in all three cases as a rare species (category « $3 \gg)$.

\section{Acknowledgements}

This study was supported by the Russian Foundation for Basic Research (project No. 18-04-00988) and the Ministry of Education and Science of the Russian Federation (project No. AAAA-A18-118012690106-7, AAAA-A18-118012690105-0, AAAA-A18-118012690099-2). We are grateful to A.A. Przhiboro (Zoological Institute RAS), E.S. Chertoprud (Lomonosov Moscow State University), A.G. Sabeev and V.V. Dobronosov (National Park «Alania») for their help during fieldwork; D.G. Seleznev (Papanin Institute for Biology of Inland Waters RAS) for the consultations, and A.G. Kirejtschuk (Zoological Institute RAS) for providing comparative material of some species from the collection of Zoological Institute.

\section{References}

Abellán P., Benetti C.J., Angus R.B., Ribera I. 2011. A review of Quaternary range shifts in European aquatic 
Coleoptera. Global Ecology and Biogeography 20(1): 87-100. DOI: 10.1111/j.1466-8238.2010.00572.x

Akatov V.V. 1986. Main trends in the overgrowth of alpine lakes in the North-Western Caucasus. Botanicheskii Zhurnal 71(6): 798-804. [In Russian]

Akatova T.V. 2002. Mosses of the Caucasian Reserve. Arctoa 11: 179-204. [In Russian]

Angus R. 1992. Insecta: Coleoptera: Hydrophilidae: Helophorinae. Süsswasserfauna von Mitteleuropa 20[10(2)]: 1-144.

Balian E.V., Segers H., Lévêque C., Martens K. 2008. The Freshwater Animal Diversity Assessment: an overview of the results. Hydrobiologia 595(1): 627-637. DOI: 10.1007/s10750-007-9246-3

Barsegyan A.M. 1978. Dynamics of vegetation of Armenia wetlands. In: Genesis and dynamics of mires. Vol. 1. Moscow: Publisher of Moscow State University. P. 193-197. [In Russian]

Botch M.S., Mazing V.V. 1979. Mire ecosystems in the USSR. Leningrad: Nauka. 187 p. [In Russian]

Boukal D.S., Boukal M., Fikaček M., Hajek J., Klečka J., Skalicky S., Stastny J., Travniček D. 2007. Catalogue of water beetles of the Czech Republic (Coleoptera: Sphaeriusidae, Gyrinidae, Haliplidae, Noteridae, Hygrobiidae, Dytiscidae, Helophoridae, Georissidae, Hydrochidae, Spercheidae, Hydrophilidae, Hydraenidae, Scirtidae, Elmidae, Dryopidae, Limnichidae, Heteroceridae, Psephenidae). Klapalekiana 43(Suppl.): 1-289.

Busch E.A., Busch N.A. 1926. Botanical research in the Central Caucasus in 1925. Proceedings of the Botanical Museum of AS USSR 19: 163-181. [In Russian]

Busch N.A. 1932. On the mires limnogeneus origin of the Balkaria and Digoria. Proceedings of the Botanical Museum of AS USSR 25: 7-16. [In Russian]

Cuppen J.G.M. 1986. The influence of acidity and chlorinity on the distribution of Hydroporus species (Coleoptera, Dytiscidae) in the Netherlands. Entomologica Basiliensia 11: 327-336.

Dokturowsky W.S. 1927. On the boundaries of Sphagnum mires and mires districts. Torfyanoe delo 8: 185-188. [In Russian]

Dokturowsky W.S. 1936. Materials on the study of Transcaucasia. Pochvovedenie 2: 183-202. [In Russian]

Doroshina G.Ya., Nikolajev I.A. 2017. Sphagnum mosses of Tarskoe bog (North Ossetia) and their protection. In: Actual problems of chemistry, biology and biotechnology: Proceeding of the XI All-Russian Scientific Conference (May 18-20, 2017). Vladikavkaz: SGU Publishing House. P. 20-24. [In Russian]

Doroshina G.Ya., Nikolajev I.A. 2018. Sphagnum mosses (Sphagnaceae, Bryophyta) of mires Chefandzar and Masota in North Ossetia (Caucasus). Novosti Sistematiki Nizshikh Rastenii 52(2): 455-462. DOI: 10.31111/ nsnr/2018.52.2.455 [In Russian]

Dylevskaya I.V. 1976. Study of Sphagnum mosses of Georgia. Proceedings of the Institute of Botany of Georgian SSR 28: 35-40. [In Russian]
Eyre M.D., Ball S.G., Foster G.N. 1986. An initial classification of the habitats of aquatic Coleoptera in north-east England. Journal of Applied Ecology 23(3): 841-852. DOI: $10.2307 / 2403938$

Fery H. 2009. New species of the Hydroporus longulusgroup from Iran, Armenia and Turkey with a synopsis of the group (Coleoptera: Dytiscidae). Acta Entomologica Musei Nationalis Pragae 49(2): 529-558.

Fery H., Petrov P.N. 2005. Nomenclatural, taxonomic, and faunistic notes on selected species of Hydroporus Clairville, 1806 (Coleoptera: Dytiscidae). Russian Entomological Journal 14(4): 251-262.

Fikáček M., Angus R.B., Gentili E., Jia F., Minoshima Y.N., Prokin A., Przewoźny M., Ryndevich S.K. 2015a. Family Helophoridae Leach, 1815. In: I. Löbl, D. Löbl (Eds.): Catalogue of Palaearctic Coleoptera. Vol. 2/1. Revised and Updated Edition. Leiden-Boston: Brill. P. 25-33.

Fikáček M., Angus R.B., Gentili E., Jia F., Minoshima Y.N., Prokin A., Przewoźny M., Ryndevich S.K. 2015b. Family Hydrophilidae Latreille, 1802. In: I. Löbl, D. Löbl (Eds.): Catalogue of Palaearctic Coleoptera. Vol. 2/1. Revised and Updated Edition. Leiden-Boston: Brill. P. 37-76.

Golub V.B., Tsurikov M.N., Prokin A.A. 2012. Collections of insects: collecting, handling and keeping of the material. Moscow: KMK Scientific Press Ltd. 339 p. [In Russian]

Hájek J. 2017. Family Dytiscidae Leach, 1815. In: I. Löbl, D. Löbl (Eds.): Catalogue of Palaearctic Coleoptera. Vol. 1. Revised and updated edition. Archostemata - Myxophaga - Adephaga. LeidenBoston: Brill. P. 844-914.

Hansen M. 1987. The Hydrophiloidea (Coleoptera) of Fennoscandia and Denmark. Fauna Entomologica Scandinavica 18: 1-254.

Jäch M.A. 1987. New and little known Hydraena s. str. from Western Asia (Hydraenidae, Coleoptera). Zeitschrift der Arbeitsgemeinschaft Österreichischer Entomologen 39: 51-55.

Jäch M.A. 2015. Family Hydraenidae Mulsant, 1844. In: I. Löbl, D. Löbl (Eds.): Catalogue of Palaearctic Coleoptera. Vol. 2/1. Revised and Updated Edition. LeidenBoston: Brill. P. 130-162.

Jäch M.A., Balke M. 2008. Global diversity of water beetles (Coleoptera) in freshwater. Hydrobiologia 595(1): 419 442. DOI: 10.1007/978-1-4020-8259-7_43

Joosten H., Tanneberger F., Moen A. (Eds.) 2017. Mires and peatlands of Europe: Status, distribution and conservation. Stuttgart: Schweizerbart Science Publishers. $780 \mathrm{p}$.

Juliano S.A. 1991. Changes in structure and composition of an assemblage of Hydroporus species (Coleoptera, Dytiscidae) along a pH gradient. Freshwater Biology 25(2): 367-378. DOI: 10.1111/ j.1365-2427.1991.tb00499.x 
Katz N.Ya. 1971. Swamps of the Earth. Moscow: Nauka. 295 p. [In Russian]

Knyasev A.V., Savinetsky A.B., Gey N.A. 1992. Holocene history of vegetation in North Ossetia. In: L.G. Dinesman (Ed.): Historical ecology of wild and domestic ungulates: History of pasture ecosystems. Moscow: Nauka. P. 84-108. [In Russian]

Mani M.S. 1968. Ecology and Biogeography of High Altitude Insects. Series Entomologica. Vol. 4. The Hague: Dr. W. Junk N. V. Publisher. 528 p.

Neustadt M.I. 1957. History of forests and paleogeography of the USSR in the Holocene. Moscow: Publishing House of AN SSSR. 404 p. [In Russian]

Nilsson A.N., Holmen M. 1995. The aquatic Adephaga (Coleoptera) of Fennoscandia and Denmark. II. Dytiscidae. Fauna Entomologica Scandinavica 32: 1-188.

Panjutin P.S. 1942. Mires of Colchide. Botanicheskii Zhurnal of USSR 27(5): 94-107. [In Russian]

Philippov D.A., Prokin A.A., Przhiboro A.A. 2017. Methods and methodology of hydrobiological study of mires: tutorial. Tyumen: Publisher of the Tyumen State University. 207 p. [In Russian]

Ponomarenko A.G., Prokin A.A. 2015. Review of paleontological data on the evolution of aquatic beetles (Coleoptera). Paleontological Journal 49(13): 1383-1412. DOI: $10.1134 / \mathrm{S} 0031030115130080$

Prokin A.A. 2018. First record of Hebrus ruficeps (Heteroptera: Hebridae) from the Caucasus. Zoosystematica Rossica 27(2): 259-260. DOI: 10.31610/ $\mathrm{zsr} / 2018.27 .2 .259$

Prokin A.A., Sazhnev A.S. 2019. New records of beetles from families Haliplidae, Dytiscidae, Hydraenidae, Helophoridae, Hydrophilidae, Scirtidae and Chrysomelidae (Coleoptera) from the North Caucasus. Caucasian Entomological Bulletin 1. (In press).

Prokina K.I., Philippov D.A. 2017. Materials on the freeliving heterotrophic flagellates of North and South Ossetia mires. Proceedings of IBIW RAS 79(82): 177-182. DOI: 10.24411/0320-3557-2017-10038 [In Russian]

Rydin H., Jeglum J.K. 2013. The Biology of Peatlands. Second Edition. Oxford University Press. 382 p.

Sánchez-Fernández D., Abellán P., Mellado A., Velasco J., Millan A. 2006. Are water beetles good indicators of biodiversity in Mediterranean aquatic ecosystems? The case of the Sigura river basin (SE Spain). Biodiversity and Conservation 15(14): 4507-4520. DOI: 10.1007/ s10531-005-5101-X

Tarnogradsky D.A. 1947. Microflora and microfauna of the peat bogs of the Caucasus. 2. «Tarskoe» peaty moor.
Proceedings of the North-Ossetia Agrarian Institute 1/14: 19-34. [In Russian]

Tarnogradsky D.A. 1957. Microflora and microfauna of the peat bogs of the Caucasus. 7. Sphagnetums of Caucasus State Reserve. Proceedings of the North-Ossetia Agrarian Institute 19: 31-39. [In Russian]

Tarnogradsky D.A. 1959. Microflora and microfauna of the peat bogs of the Caucasus. 8. Sedge-Sphagnum lakes in the upper course of Balkarskiy Cherek River. Proceedings of the North-Ossetia Agrarian Institute 6(3): 3-91. [In Russian]

Tsalolikhin S.Ya. (Ed.). 2001. Key to freshwater invertebrates of Russia and adjacent lands. Vol. 5. Trichoptera, Lepidoptera, Coleoptera, Megaloptera, Neuroptera. St. Petersburg: Nauka. 836 p. [In Russian]

Tumadzanov I.I. 1955. To the post-Pliocene history of forest vegetation in the North Caucasus. Proceedings of the Tbilisi Botanical Institute 17: 161-219. [In Russian]

Usseglio-Polatera P., Richoux P., Bournaud M., Tachet H. 2001. A functional classification of benthic macroinvertebrates based on biological and ecological traits: application to river condition assessement and stream management. Archiv für Hydrobiologie 139(1): 53-83.

van Vondel B.J., Holmen M., Petrov P.N. 2006. Review of the Palaearctic and Oriental species of the subgenus Haliplus s. str. (Coleoptera: Haliplidae: Haliplus) with descriptions of three new species. Tijdschrift voor Entomologie 149: 227-273.

van Vondel B.J. 2017. Family Haliplidae Aubé, 1836. In: I. Löbl, D. Löbl (Eds.): Catalogue of Palaearctic Coleoptera. Vol. 1. Archostemata - Myxophaga - Adephaga. Revised and updated edition. Leiden: Brill. P. 838-843.

Voronikhin N.N. 1934. Microflora of peatlands of Balkaria. Botanicheskii Zhurnal of USSR 19(5): 512-517. [In Russian]

Yemel'yanov A.F. 1974. Proposals on the classification and nomenclature of ranges. Entomological Review 53(3): 11-26.

Zaitzev F.A. 1927. Diving beetles of the Caucasus (Coleoptera, Dytiscidae). Proceedings of the North Caucasus Hydrobiological Station at the Agricultural Institute 2(1): 1-42. [In Russian]

Zaitzev F.A. 1953. Coleoptera. Dytiscidae and Gyrinidae. In: Fauna USSR 4(58). Moscow, Leningrad: Publishing House of AS USSR. 372 p. [In Russian]

Zedelmeyer O.M. 1927. Distribution of peat bogs and Sphagnum mosses in Caucasus. Torfyanoe delo 7: 153-156. [In Russian]

Zerov D.K. 1935. Sphagnum mosses in Caucasus. Journal of Botany Institute of Ukrainian Academy of Science 6: 25-43. [In Ukrainian] 


\title{
ВОДНЫЕ ЖЕСТКОКРЫЛЫЕ (INSECTA: COLEOPTERA) НЕКОТОРЫХ ТОРФЯНЫХ БОЛОТ СЕВЕРНОГО КАВКАЗА
}

\author{
А. А. Прокин ${ }^{1,2, *}$, А. С. Сажнев ${ }^{1}$, Д. А. Филиппов ${ }^{1}$ \\ ${ }^{1}$ Институт биологии внутренних вод им. И.Д. Папанина РАН, Россия \\ *e-mail:prokina@mail.ru \\ ${ }^{2}$ Череповеикий государственный университет, Россия
}

\begin{abstract}
Горные болота занимают всего $0.1 \%$ территории Кавказа и встречаются на высотах от 600 м до 3400 м. В отличие от растительности и стратиграфии, энтомофауна торфяных болот изучена слабо. Целью наших исследований было впервые выявить состав фауны водных жуков сфагновых и осоково-сфагновых болот Северного Кавказа, описать её зоогеографические особенности, региональную специфику и факторы, определяющие видовое разнообразие и состав населения отдельных болот. Полевые исследования выполнены в мае - июне и сентябре 2018 г. на восьми болотах Северной Осетии (Тарское, Чифандзар, два сфагновых болота на горе Кубус) и Кабардино-Балкарии (3 сфагновых болота в окрестностях села Верхняя Балкария и нарзанное болото Уштулу). Материал собран на внутриболотных водоёмах и водотоках с помощью кошения гидробиологическим сачком Бальфур-Брауна, индивидуального отлова аквариумными сачками в мелководных водоемах и при вытаптывании из сфагнет. Всего было обнаружено 25 видов водных жесткокрылых из 6 семейств (Gyrinidae - 1, Haliplidae - 1, Dytiscidae - 13, Helophoridae - 2, Hydrophilidae - 7, Hydraenidae - 1). Среди них встречен ряд эндемиков Кавказа; борео-монтанные виды, являющиеся в регионе ледниковыми реликтами. Формирование локальных фаун водных жуков болот Северного Кавказа имеет региональные особенности, зависит от высотных характеристик, типологического разнообразия внутриболотных водных объектов и физико-химических показателей воды. Рекомендуется создание новых ООПТ на сфагновых болотах в Кабардино-Балкарии в окрестностях села Верхняя Балкария. Рекомендуем с основной охранной мерой - охрана горных сфагновых болот как уникальных местообитаний - для внесения в Красную книгу Кабардино-Балкарии борео-монтанные виды: Hydroporus incognitus, Hydroporus nigellus; в Красную книгу Северной Осетии: Hydroporus nigellus.
\end{abstract}

Ключевые слова: видовое богатство, зоогеография, Кабардино-Балкария, осоково-сфагновые болота, охрана, региональная специфика, Северная Осетия, сфагновые болота, фауна 